\title{
Solid pseudopapillary tumor of the pancreas: Clinical features, diagnosis and treatment
}

\author{
Carlos Anselmo lima ${ }^{1 *}$, Angela Silva ${ }^{2}$, Carlos Alves $^{1}$, Antonio Alves Jr. ${ }^{3}$, Sonia Lima ${ }^{3}$, Elisanio Cardoso ${ }^{4}$, Erika Brito ${ }^{3}$, \\ Matheus Macedo-Lima ${ }^{5}$, Divaldo Lyra JR. ${ }^{2}$, Pollyanna Lyra ${ }^{6}$, Marcia Macedo Lima ${ }^{3}$ \\ ${ }^{1}$ University Hospital, Universidade Federal de Sergipe (UFS), and Oncology Department, Hospital de Urgências de Sergipe (HUSE/SES), Aracaju, SE, Brasil \\ ${ }^{2}$ Graduate Program in Health Sciences, UFS. University Hospital, UFS, Aracaju, SE, Brasil \\ 3University Hospital, UFS, Aracaju, SE, Brasil \\ ${ }^{4}$ Hospital São Lucas, Aracaju, SE, Brasil \\ ${ }^{5}$ Neurosciences and Behavior Graduate Program, UMass, USA/Capes, Brazil \\ ${ }^{6}$ Graduate Program in Health Sciences, UFS, Aracaju, SE, Brazil
}

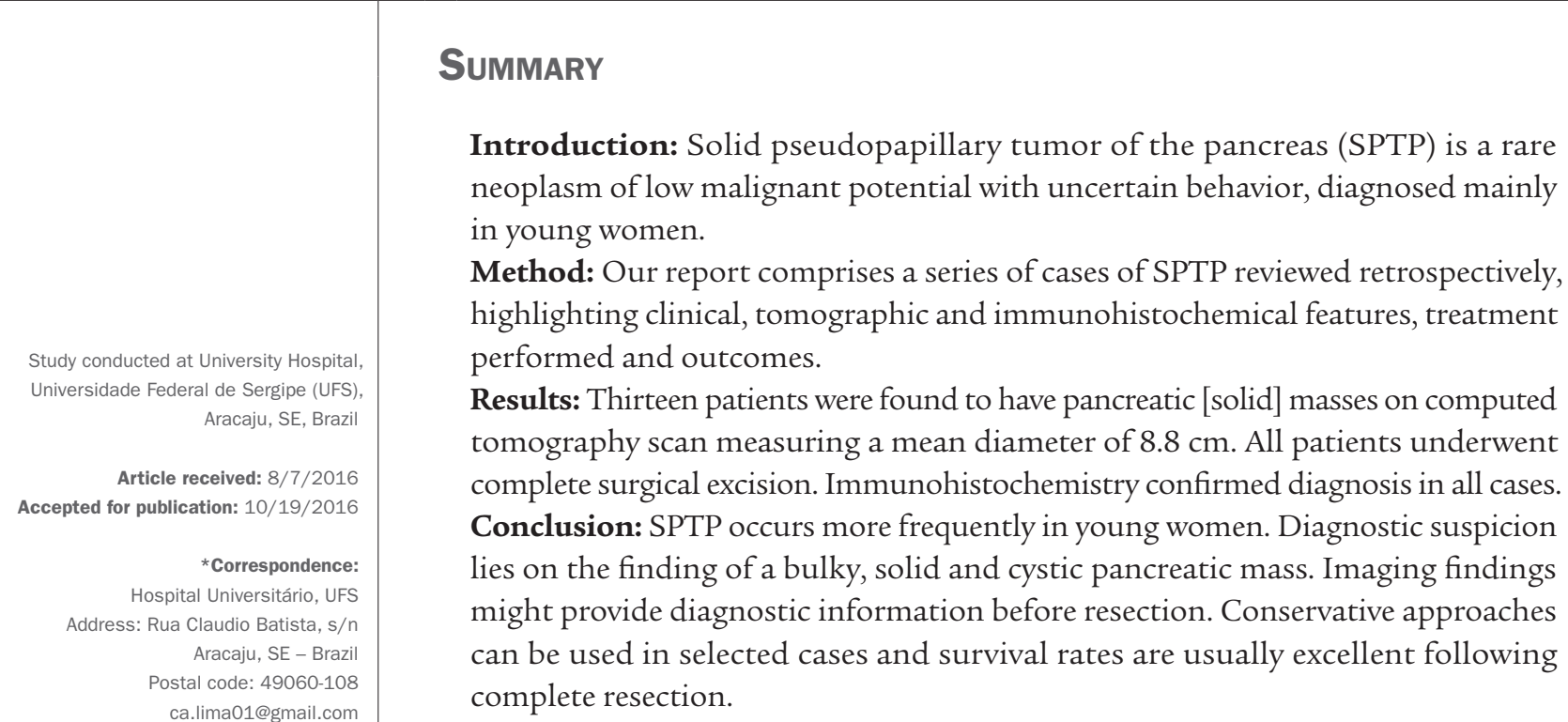

http://dx.doi.org/10.1590/1806-9282.63.03.219

Keywords: pancreatic neoplasms, surgery, female, adolescent, immunohistochemistry.

\section{INTRODUCTION}

Solid pseudopapillary tumor of the pancreas (SPTP) is a rare entity of low potential of malignancy and uncertain behavior. It comprises about 1 to $2 \%$ of exocrine tumors ${ }^{1-3}$ and $13 \%$ of surgically excised pancreatic lesions. ${ }^{1}$

Frantz was the first to report this entity, describing a papillary neoplasia with solid and cystic features, questioning its nature to be either benign or malignant, and diagnosing it as a non-functioning islet cell tumor. ${ }^{2}$ Young women in the second and third decades of life are primarily affected, ${ }^{2}$ with a ratio of 1:10 compared to men. ${ }^{3}$

Patients with SPTP more often present vague abdominal symptoms and a palpable mass. Computed tomography scan is useful to identify a cystic and calcified lesion, also determining its diameter and possibility of invading adjacent structures. Physicians have reported this neoplasm more frequently in the past few years, based not only on a better understanding of its clinical charac- teristics, but also on immunohistochemical aspects. Its low malignant potential provides excellent long-term survival after surgical excision. ${ }^{4,5}$

The present article describes clinical features and management of this uncommon pancreatic malignancy through a series of cases.

\section{Method}

From August 2001 to May 2015, we found records of 12 patients with SPTP managed in three different hospitals in the municipality of Aracaju, Sergipe, Brazil and one managed elsewhere. We conducted a retrospective descriptive analysis, including the following variables: sex, age, diameter and site of the lesion, clinical presentation, treatment performed, and follow-up. All tumors were resected, fixed in $10 \%$ formaldehyde, and then embedded in paraffin. Light microscopic analyses followed by immunohistochemistry confirmed the diagnosis. 


\section{RESULTS}

Table 1 presents demographic, clinical and pathologic findings. All patients were female with mean age of 27 years, ranging from 16 to 39 years. Preoperative CT scans of the abdomen (Figure 1) showed lesions with various degrees of solid and liquid material and no invasion into surrounding tissues.

Eleven (11) patients underwent open surgical excisions and two had laparoscopic resections. Resected specimens revealed bulky, round, soft and brown tumors presenting solid areas and hollow spaces filled with debris on section analysis. Microscopic analysis revealed layers of uniform cells with both endocrine and exocrine features in arrangements resembling rosettes around a fibrous core. More frequently, immunohistochemical examinations showed positivity for progesterone receptors and $\alpha 1$-antitrypsin, as shown in Table 2.

Patients had uneventful postoperative courses with no evidence of residual neoplasia, and, at the moment of this study, they are all well and free of disease.

\section{Discussion}

All of the SPTP cases reported here were in females with mean age of 27 years, the youngest being 16 and the oldest 39 at admission. Most reports in the literature reported cases of women in the second and third decades of life. Few cases have been reported in men., ${ }^{6,7}$

SPTP has been reported in the literature since 1933 and its incidence seems to be increasing mainly due to better diagnostic techniques, including reviews of past cases. ${ }^{3,8}$
Patients often present bulky tumors, with mean diameter around $10 \mathrm{~cm}$. Early signs and symptoms are vague and non-specific, leading to a delay in diagnosis. ${ }^{6,9-11}$ The same occurred with our patients, with nine presenting abdominal masses and tenderness at admission; one patient had associated vomiting due to gastric outlet obstruction; one had diabetes; and three other had no complaints and tumors were discovered in routine abdominal sonograms. The body and tail of the pancreas more often harbor these tumors and seldom do they invade adjacent tissues. Similarly, eight of our cases were in the body-tail region and five in the head of the pancreas.

All of the tumors we report were completely excised. Authors have reported high resection rates and rarely any residual disease. Recurrence is low after complete resection, which is the only way to achieve a cure. ${ }^{12}$

In our series, correct diagnosis followed surgical resection. Definitive diagnosis usually occurs after surgical resection and pathologic examination of the specimen; however, sonography and tomography features of a bulky, solid and cystic tumor, especially in young women, lead to suspicion of a papillary cystic neoplasm. ${ }^{6,13}$ Some authors consider CT scan the most precise means of diagnosis. ${ }^{6,8,13}$ On the other hand, findings with magnetic resonance imaging appear to correspond more precisely to the pathological features. ${ }^{14}$ The cytological appearance of these tumors has been described and percutaneous needle aspiration can be used. However, this has been questioned because of the risk of needle-site implants. ${ }^{15}$ Whether the pancreatic masses are discovered after minor symptoms or

TABLE 1 Demographic, clinical and pathological features of 13 patients with solid pseudopapillary pancreatic tumor.

\begin{tabular}{llllllll} 
Cases & Sex & Age & Site & Diameter $(\mathbf{c m})$ & Presentation & Type of resection & Follow-up \\
\hline 1 & F & 21 & H & 16 & Mass & PD & 165 \\
\hline 2 & F & 16 & B/T & 15 & Mass, pain & Distal P & 156 \\
\hline 3 & F & 22 & B/T & 10 & Mass, emesis & Distal P + Spl & 154 \\
\hline 4 & F & 20 & B/T & 9 & Mass & Distal P & 151 \\
\hline 5 & F & 39 & B/T & 14 & Mass & Distal P + Spl & 90 \\
\hline 6 & F & 19 & H & 8 & Pain & Enuc & 89 \\
\hline 7 & F & 17 & B/T & 6 & Asymptomatic & VLP Res & 85 \\
\hline 8 & F & 32 & B/T & 8.5 & Mass, pain & Distal P & 81 \\
\hline 9 & F & 34 & B/T & 7.7 & Pain & Distal P & 64 \\
\hline 10 & F & 34 & H & 3.1 & Pain & PD & 29 \\
\hline 11 & F & 37 & H & 7.5 & Diabetes & PD & 12 \\
\hline 12 & F & 37 & B & 4.5 & Asymptomatic & Partial R & 9 \\
\hline 13 & F & 37 & H & 5.2 & Asymptomatic & PD & 4 \\
\hline Mean & - & 28 & - & - & - & 83.8
\end{tabular}

F: female; H: pancreatic head; B/T: body/tail of pancreas; B: pancreatic body; PD: pancreatoduodenectomy; Distal P: distal pancreatectomy; Spl: splenectomy; Enuc: enucleation; VLP Res: videolaparoscopic resection; Partial R: partial resection. 


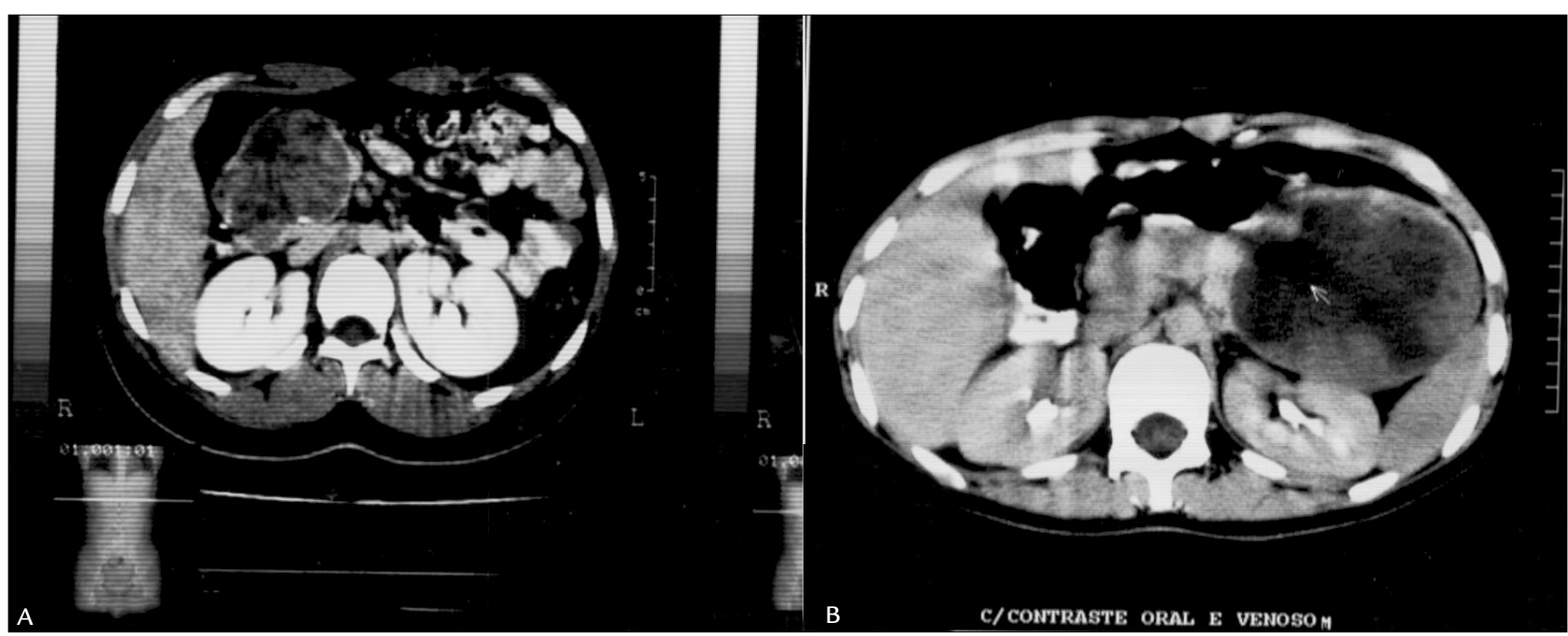

FIGURE 1 CT scan of pancreatic masses displaying (A) solid and (B) cystic features (cases 4 and 2).

TABLE 2 Immunohistochemical features of the tumors.

\begin{tabular}{|c|c|c|c|c|c|c|c|c|c|c|c|c|c|}
\hline Marker & Cas & & & & & & & & & & & & \\
\hline & 1 & 2 & 3 & 4 & 5 & 6 & 7 & 8 & 9 & 10 & 11 & 12 & 13 \\
\hline$\alpha 1$-antitrypsin & + & + & + & - & + & + & + & + & + & NT & NT & NT & NT \\
\hline Chromogranin A & - & - & - & - & - & - & + & + & + & - & + & - & - \\
\hline Progesterone receptor & + & + & + & + & + & + & + & + & + & + & + & NT & - \\
\hline $\mathrm{AE} 1 / \mathrm{AE} 3$ & NT & - & - & - & - & + & - & + & + & + & - & + & - \\
\hline Synaptophysin & + & - & - & - & - & - & + & + & - & + & - & NT & - \\
\hline Vimentin & NT & NT & NT & NT & + & NT & + & NT & NT & NT & NT & NT & + \\
\hline CD 10 & NT & NT & NT & NT & - & NT & + & & NT & + & + & + & + \\
\hline$\beta$-catenin & NT & NT & NT & NT & NT & NT & + & NT & & + & + & + & + \\
\hline
\end{tabular}

NT: not tested; (+): positive; (-): negative.

incidentally, plain characterization of the tumors is paramount in order to identify them as benign, premalignant or malignant lesions. We recommend image characterization with contrast-enhanced helical CT scan. The decision to proceed with needle biopsy, as seen in case 13 , should be made to rule out a benign neoplasm that could be managed without surgery. In addition, determination of CA 19.9 status might help defining management.

Light microscopy defines the histopathological findings, which comprises solid areas alternating with pseudopapillary formation, cellular degeneration, including cholesterol clefts and aggregates of foaming histiocytes, uniform cells showing endocrine and exocrine characteristics, and clusters of cells arranged around a fibrovascular core. ${ }^{4,16,17}$ More often, reported immunohistochemical aspects include positivity for progesterone receptors, vimentin, neuron-specific enolase (NSE) and $\alpha 1$-antitrypsin. ${ }^{18}$ In our study, all cases tested were positive for progesterone receptors. Some authors state that these receptors play an important role in tumor growth, but their etiology remains unclear. ${ }^{1,19}$ We also found positivity for vimentin, $\alpha 1$-antitrypsin and synaptophisin. Tang et al. reported some histological findings suggesting unfavorable prognosis, such as necrosis, nuclear atypia, high mitosis rate, and sarcomatoid areas. ${ }^{19}$ None of these were found in our cases, probably anticipating good outcomes.

Due to the excellent prognosis after surgical excision, early reports proposed SPTP to be benign. Current opinion is that these tumors have low malignant potential. ${ }^{5,18,20}$ The possibility of metastasis is low and the outcome is usually favorable after complete excision, but there are reports of involvement of the liver, lymph nodes, and peritoneum. Adjuvant treatment is not indicated but there are a few reports on the administration of chemo and radiation therapy following incomplete resection. ${ }^{21,22}$ None of our cases had adjuvant chemo or radiation treatment. 
Regarding the origin of these tumors, some researchers suggest that because of the early age of occurrence, there would be hormonal dependence, but only progesterone receptors have been found to be expressed. More recently, researchers have found nuclear and cytoplasmic accumulation of mutant genes for $\beta$-catenin. ${ }^{18}$

Since these are low-grade tumors and especially surrounded by a fibrous capsule, some surgeons advocate simple enucleation of the lesion. Nevertheless, pancreatoduodenectomy and distal pancreatic resection are the procedures most often employed. Lymphatic dissection is not recommended. ${ }^{3,6,23}$ In our series of cases, we performed head and distal resections, enucleation and two laparoscopic excisions. The decision to perform resection in all cases was based on the sole presence of a pancreatic mass and the addition of one core biopsy in one of the cases. Open surgery is more feasible in our institution, but eventually is surpassed by laparoscopic resection. However pancreatic laparoscopic procedures demand great expertise, that can be achieved by well-trained surgeons.

Preoperative core biopsy should be considered so that management of solid pseudopapillary tumors can be done surgically. Laparoscopic resection may be a better option but the choice of open pancreatectomy cannot be ruled out, especially in public health institutions. To date, all patients are alive and free of disease.

\section{Conclusion}

Both our case series and those reported in the literature revealed that SPTP occurs more frequently in young women. Diagnostic suspicion lies on the finding of a bulky, solid and cystic pancreatic mass. Imaging findings might provide diagnostic information before resection. Conservative approaches can be used in selected cases. Long-term survival usually follows complete resection.

\section{AcKNoWledgments}

We thank Dr. Ademar Lopes for kindly allowing us to include one of his cases.

\section{Conflict of interest}

The authors declare no conflict of interest.

\section{Resumo}

Tumor sólido pseudopapilífero do pâncreas: características clínicas, diagnóstico e tratamento

Introdução: $O$ tumor sólido pseudopapilífero do pâncreas é uma neoplasia rara de baixo potencial de malignidade e com comportamento incerto, diagnosticado principalmente em mulheres jovens.

Método: Uma série de casos dessa patologia é revisada retrospectivamente, focalizando os aspectos clínicos, tomográficos e imuno-histoquímicos, o tratamento realizado e o desfecho.

Resultados: Foram avaliadas 13 pacientes com massas pancreáticas, por meio de tomografia computadorizada, com diâmetro médio de $8,8 \mathrm{~cm}$. Todas as pacientes submeteram-se a ressecção cirúrgica completa. A imuno-histoquímica confirmou o diagnóstico em todos os casos. Conclusão: Esses tumores ocorrem frequentemente em mulheres jovens. Suspeita-se do diagnóstico ao encontrar uma volumosa tumoração sólido-cística no pâncreas. As imagens podem fornecer informações diagnósticas antes da ressecção. Podem-se empregar abordagens conservadoras em pacientes selecionados, e a sobrevida geralmente é excelente com a ressecção completa.

Palavras-chave: neoplasias pancreáticas, cirurgia, feminino, adolescente, imuno-histoquímica.

\section{RefEREnCES}

1. Goh BK, Tan YM, Cheow PC, Chung AY, Chow PK, Wong WK, et al. Solid pseudopapillary neoplasms of the pancreas: an updated experience. J Surg Oncol. 2007; 95(8):640-4.

2. Frantz V. Tumors of the pancreas. In: Frantz V, editor. Atlas of tumor pathology. Washington: Armed Force Institute of Pathology; 1959. p. 32-3.

3. Yu PF, Hu ZH, Wang XB, Guo JM, Cheng XD, Zhang YL, et al. Solid pseudopapillary tumor of the pancreas: a review of 553 cases in Chinese literature. World J Gastroenterol. 2010; 16(10):1209-14

4. Ganeshan DM, Paulson E, Tamm EP, Taggart MW, Balachandran A, Bhosale P. Solid pseudo-papillary tumors of the pancreas: current update. Abdom Imaging. 2013; 38(6):1373-82.

5. Butte JM, Brennan MF, Gönen M, Tang LH, D’Angelica MI, Fong Y, et al Solid pseudopapillary tumors of the pancreas. Clinical features, surgical outcomes, and long-term survival in 45 consecutive patients from a single center. J Gastrointest Surg. 2011; 15(2):350-7.

6. Reddy S, Cameron JL, Scudiere J, Hruban RH, Fishman EK, Ahuja N, et al. Surgical management of solid-pseudopapillary neoplasms of the pancreas (Franz or Hamoudi tumors): a large single-institutional series. J Am Coll Surg. 2009; 208(5):950-7.

7. Romics L, Oláh A, Belágyi T, Hajdú N, Gyurus P, Ruszinkó V. Solid pseudopapillary neoplasm of the pancreas--proposed algorithms for diagnosis and surgical treatment. Langenbecks Arch Surg. 2010; 395(6):747-55.

8. Papavramidis T, Papavramidis S. Solid pseudopapillary tumors of the pancreas: review of 718 patients reported in English literature. J Am Coll Surg. 2005; 200(6):965-72.

9. Kang CM, Kim KS, Choi JS, Kim H, Lee WJ, Kim BR. Solid pseudopapillary tumor of the pancreas suggesting malignant potential. Pancreas. 2006; 32(3):276-80.

10. Freda F, Procaccini E, Ruggiero R, Antropoli M, Manganiello A, Nunziata L, et al. Solid-cystic pseudopapillary tumor of pâncreas: description of two cases and literature review. Tumori. 2007; 93(5):522-5.

11. Costa SRP, Henriques AC, Godinho CA, Miotto MJ, Costas MC, Horta SH, et al. Tumor papilar sólido-cístico do pâncreas: aspectos clínico-radiológicos e resultados cirúrgicos em cinco pacientes operados. Einstein. 2007; 5(2):161-5.

12. Serrano PE, Serra S, Al-Ali H, Gallinger S, Greig PD, McGilvray ID, et al. Risk factors associated with recurrence in patients with solid pseudopapillary tumors of the pancreas. JOP. 2014; 15(6):561-8. 
13. Miao F, Zhan Y, Wang XY, Wang DB, Chen KM, Tang AR, et al. CT manifestations and features of solid cystic tumors of the pancreas. Hepatobiliary Pancreat Dis Int. 2002; 1(3):465-8

14. Nakatani K, Watanabe Y, Okumura A, Nakanishi T, Nagayama M, Amoh Y, et al. MR imaging features of solid-pseudopapillary tumor of the pancreas. Magn Reson Med Sci. 2007; 6(2):121-6.

15. Pettinato G, Di Vizio D, Manivel JC, Pambuccian SE, Somma P, Insabato L. Solid-pseudopapillary tumor of the pancreas: a neoplasm with distinct and highly characteristic cytological features. Diagn Cytopathol. 2002; 27(6):325-34

16. Santini D, Poli F, Lega S. Solid-papillary tumors of the pancreas: histopathology. JOP. 2006; 7(1):131-6.

17. Ye J, Ma M, Cheng D, Yuan F, Deng X, Zhan Q, et al. Solid-pseudopapillary tumor of the pancreas: clinical features, pathological characteristics, and origin. J Surg Oncol. 2012; 106(6):728-35.

18. Li L, Li J, Hao C, Zhang C, Mu K, Wang Y, et al. Immunohistochemical evaluation of solid pseudopapillary tumors of the pancreas: the expression pattern of CD99 is highly unique. Cancer Lett. 2011; 310(1):9-14
19. Tang LH, Aydin H, Brennan MF, Klimstra DS. Clinically aggressive solid pseudopapillary tumors of the pancreas: a report of two cases with components of undifferentiated carcinoma and a comparative clinicopathologic analysis of 34 conventional cases. Am J Surg Pathol. 2005; 29(4):512-9.

20. Kim CW, Han DJ, Kim J, Kim YH, Park JB, Kim SC. Solid pseudopapillary tumor of the pancreas: can malignancy be predicted? Surgery. 2011; 149(5):625-34.

21. Strauss JF, Hirsch VJ, Rubey CN, Pollock M. Resection of a solid and papillary epithelial neoplasm of the pancreas following treatment with cis-platinum and 5-fluorouracil: a case report. Med Pediatr Oncol. 1993; 21(5):365-7.

22. Fried P, Cooper J, Balthazar E, Fazzini E, Newall J. A role for radiotherapy in the treatment of solid and papillary neoplasms of the pancreas. Cancer $1985 ; 56(12): 2783-5$.

23. Zhang RC, Yan JF, Xu XW, Chen K, Ajoodhea H, Mou YP. Laparoscopic vs open distal pancreatectomy for solid pseudopapillary tumor of the pancreas World J Gastroenterol. 2013; 19(37):6272-7. 